Environment Conservation Journal 15(3) 19-28, 2014

ISSN 0972-3099 (Print) 2278-5124 (Online)

Abstracted and Indexed

\title{
Effect of food on seasonal response in Indian weaver bird (Ploceus philippinus)
}

\author{
Shikha Malik, Rohit Kumar Pandey and Sanjay Kumar Bhardwaj凶
}

Received:25.07.2014

Accepted:19.10.2014

\begin{abstract}
We investigated the effect of normal (adlib) and supplementary food on body mass, testes growth, moult and plumage color in Indian weaver birds. Birds intially were kept under natural day length (NDL) and then exposed to short day lengths ( $8 \mathrm{~h}$ light: $16 \mathrm{~h}$ darkness) for at least 2 weeks before being subjected to an experimental regime. They were divided into five groups ( $n=4$ each), groups 1 and 2 were held under SDL (Short day length -8L: 16D), groups 3 and 4 were exposed to LDL (Long daylength-16L: 8D) and simultaneously group 5 held under natural day length, served as control. One group of SDL (Group 2) and LDL (group 3) as well as group 5 (NDL) were fed on grain with supplement proteinaceous food and groups 2 and 4 were fed on adlib food (grain) only. Observations on body mass, testis growth, bodymolt and plumage color were recorded bi weekly. A significant change in the body mass under both photoperiodic groups (SDL; group 2 and LDL; group 4), but the testicular growth was noticed on long day lengths (LDL: 16L: 8D) and control (NDL) group. However the supplement food modulated the testes growth, body molt, beak pigmentation and body plumage regeneration. Early feather regeneration was found in supplementary food group under long day length. It is suggested that the supplementary food, affects the timing of the development of secondary sexual characteristics.
\end{abstract}

Keywords: Body moult, Food adlib, Food supplement, Photoperiod, Testes,

\section{Introduction}

It is known that many birds use annual light-dark (photoperiod) cycle as a primary time cue in the regulation of seasonal reproduction and associated events. At given latitude, the time of light-onset and light offset change precisely and systematic manner throughout the year, and seasonal cycles of the light dark cycle does not vary yearly. Seasonal breeding and associated physiological behaviour are evolved through the development of timing mechanisms that are governed by the oscillatory systems, which are endogenous, self sustained oscillator (Aschoff,1981; Kumar et al., 2004). Organisms have ability to synchronize their physiological and behavioural activities with these exogenous environmental changes like temperature, light and humidity during different time of the day and also make them adaptable to seasonal variations (Bywlez et al., 2012).Under natural condition, these physiological and behavioural activities synchronize their phases and periods of oscillat ions with the day and night.

\section{Author's Address}

Department of ZoologyChaudharyCharan Singh University, Meerut- U.P.

E-mail:drskumar7@yahoo.com
The mechanism of oscillatory system, in regulation of the seasonal event has been studied on extensively in different organisms system, starting from Drosophila to ground squirrels (Spermo philus parryi) (Daan et al., 1991; Menegazzi et al., 2012). Birds synchronize their reproductive behaviour with periods of highest resource availability (Lack, 1968; Perrins, 1970). Breeding and other physiological activities are high energy demanding processes. In case of chick, the close synchronisation occurred between breeding and high abundance of food during chick-rearing (Daan et al., 1988). Birds have no capability for the storage of nutrients for raising their young and depend on specific protein-rich food resources and these specific food resources available only during a short period. In chick, food abundance acts as a positive stimulus for initiation of egg laying (Daan et al., 1988). So, food abundance plays an important role for initiation of gonadal development well in advance of favourable breeding conditions (Wingfield, 1980). The seasonal change in light-dark cycle provides the most reliable source of temporal information about the environment and food availability also act as a 
regulatory factor for initiation of seasonal cycles. Some previous studies have investigated the nonphotoperiodic cues that might regulate seasonal responses in the some tropical species, but food intake and other food-related cues are probably important (Hau et al., 2001; Scheuerlein and Gwinner, 2002). Some other factors, such as temperature, rainfall, food availability and social stimuli may also regulate the timing of different breeding phases, but provide only short-term predictive information. However, only few studies have examined the effects of food supplementation in a tropical resident species, and it reported the response of food supplement which introduce the earlier egg laying (Scheuerlein and Gwinner, 2002; Class and Moore, 2013). In our experimental model is the tropical passerine finch which breeds during monsoon seasons. In our earlier finding, we have reported the effect of photoperiod and different light illumination on seasonal and circadian responses on male Indian weaver birds (Pandey and Bhardwaj, 2011, 2013; Bhardwaj and Pandey, 2014). After observation of these findings, we have a question, if quality of food (normal/supplement) modulates the initiation of breeding cycle in male Indian weaver birds. We subjected different groups (five groups) of birds to determine the effect of food quality (normal/supplement) in maturation of testes and other secondary sexual characteristics in male Indian weaver bird (Ploceus philippinus).

\section{Material and Methods}

Adult male Indian weaver birds were captured (April 2013) from wild habitats in Meerut $\left(29^{\circ} 01{ }^{\circ}\right.$ $\left.\mathrm{N} ; 77^{\circ} 45^{\circ} \mathrm{E}\right)$, India, using mist net and held in an outdoor aviary $($ size $=2.7 \times 2.2 \times 1.9 \mathrm{~m})$ receiving natural day length (NDL). In the captivity, birds were acclimatized for one or two weeks and were subjected to artificial photoperiodic chambers providing short-day conditions (8h light: $16 \mathrm{~h}$ darkness; 8L: 16D). Food mainly consisted of seeds of Oryza sativa. Weaver bird is a seasonally breeding species with its breeding season extending between May and September (Ali and Ripley, 1974). Birds are social and highly gregarious and seasonal movements of this species depend upon food availability. For photoperiodic experiments, birds were housed in wire mesh cages (size 45 x 25 x $25 \mathrm{~cm}^{3}$ ), kept in light-tight photoperiodic boxes maintained at $24 \pm 2^{0} \mathrm{C}$ temperature. Fluorescent tubes or CFL lamps (14-watt cool compact fluorescent lamp; model B22 BC from Philips India Ltd.) were used for providing the day-night condition. The ON and OFF condition of light was regulated by Automatic time switches (Müller clock, Germany). Light intensity was measured by the radiometer (Macam Photometrics Ltd., Scotland). Initially birds were kept in NDL and then exposed to short day lengths $(8 \mathrm{~h}$ light: $16 \mathrm{~h}$ darkness, 8:16 LD) for at least 2 weeks before being subjected to experimental lighting schedules. Birds were divided into five groups ( $\mathrm{n}=4$ each), first two groups were exposed to SDL (8L: 16D), other two groups were exposed under LDL (16L: 8D) and group 5 was exposed to NDL (Natural day length) for about 6 months ( 24 weeks). One group of SDL and LDL and also NDL group were fed on food ad libitum with supplement food and other two groups fed on only grains (Oryza sativa). In normal food (adlib) seeds of Oryza sativa were given, but the supplement food was rich in protein and vitamins (Prepared by mixing bread crumbs, boiled eggs, cheese and multi-vitamin).

\section{Data Collection}

For observation of body mass, birds were individually wrapped in a cotton bag and weighed on a top pan balance to the accuracy of $0.1 \mathrm{~g}$. Testicular size was measured by performing laparotomy under local anesthesia as per method described by Kumar et al. (2001). Briefly, laparotomy was performed by small incision of abdominal wall between the last two ribs on the left side and testis was located within the abdominal cavity. The length and width of the left testis was measured by the spatula and testicular volume was calculated using formula $4 / 3 \pi a b^{2}$, where $a$ and $b$ represent the half of the long (length) and short (width) axes, respectively. The molt pattern was recorded by the observations on body feather and wing feathers (primaries). In body molt, whole body of the bird's was divided into 12 different regions as follows: 1 - head, 2 - neck, 3 - shoulder, 4 - back, 5 - pelvic, 6 - caudal, 7 - throat, 8 chest, 9 - abdomen, 10 - flank, 11 - shank, and 12 - sub-caudal. Each region could have a score of either 0 (old feather present) or 1 (moult: no feather or new feathers emerging) and hence the body molt 
score noticed a minimum score 0 and maximum score could be 12 (Budki et al., 2009). For recording of primaries, we followed scoring pattern as outlined by Boswell (1991), Trivedi et al. (2006) and Dixit and Singh $(2012,2013)$ in a scale of 0-5 as per the following: 0 - worn or old feather, 1 missing feather (just dropped), 2 - from a new feather papilla emerging up to one-third growth, 3 new feather attaining two-third growth, 4 - new feather grown, but still the feather growth is not fully complete and 5 - fully grown new feather (complete feather). Thus, each primary feather contains a minimum score of 0 and maximum of 5 . But, there are nine primaries on each wing, so the maximum score of each wing could have up to 45 $(9 \times 5=45)$, and for each bird a maximum score up to $90(2 \times 45)$. Minimum score could be as low as 0 . Beak color was scored in an index of $0-5$, as per scheme outlined as follows: 0 - bill straw in color (S), 1 - bill straw in color but with a little tinge of blackness (ratio - SSS:B), 2 - bill slightly blackish in color (ratio - SS:B), 3 - bill straw and black in approximately 50:50 patches (ratio - S:B), 4 - bill black with very little straw patch left (ratio - S:BB) and 5 - bill completely black (B) (Trivedi et al., 2006; Rani et al., 2007). The plumage color of head and breast of male weaver bird is change during the breeding season; the non-breeding male 'femalelike' to breeding (nuptial) male bright yellow color. The plumage color was scored on a scale of 1-3 on head and $0-5$ on breast as follows: Head $=1$ 'female-like' feathers; 2- mixed 'female like' and yellow (nuptial) feathers and 3- complete yellow feathers. Breast $=0$ - all 'female-like' (no yellow) feathers and 5- all yellow (no female-like) feathers; every 0.5 increment in this scale (e.g., $0.5,1.0$ and so on) meant $10 \%$ increase from 'female-like' to nuptial feathers (Thapliyal and Saxena, 1961; Saxena and Thapliyal, 1962; Rani et al., 2007).

\section{Blood analysis}

Blood samples were collected from each group initially, after 3 months and at the end of the experiment. Blood was collected in heparinised tube by pricking the branchial vein in clean and sterilised conditions. The collected sample was stored over $4^{\circ} \mathrm{C}$ for $24 \mathrm{hrs}$. Then collected samples were centrifuged at $3000 \mathrm{rpm}$ and serum was collected in separate vials and stored at $-20^{\circ} \mathrm{C}$ till it was assayed.

\section{Statistical analysis}

The statistical analysis was carried out using graph pad prism software (version 3.0 La Jolla, CA, USA) and significance was taken on $\mathrm{P}<0.05$.

\section{Results and Discussion}

The results of body mass and testis volume are shown in Figure 1, 2 and 3 (A-D). There was no significant change in body mass in birds exposed to 8L:16D with food adlibitum $\left(\mathrm{F}_{6,18}=5.101 \mathrm{P}=\right.$ 0.0032) and food supplement $\left(\mathrm{F}_{6,18}=3.737 \mathrm{P}=\right.$ $0.0137)$ and control group $\left[\left(\mathrm{NDL}-\mathrm{F}_{6,18}=1.058 \mathrm{P}=\right.\right.$ 0.4226; one-way RM ANOVA] (Figure 1A and C), but significant change in body mass occurred in food with supplement group under 16L:8D $\left(\mathrm{F}_{6,18}=6.425, \mathrm{P}=0.0009\right.$; one-way RM ANOVA) (Figure 2C). Testicular growth of the both groups (received food adlibitum and food supplement) of SDL (8L: 16D) were unaffected during the experimental period [(Food adlibitum: $\mathrm{F}_{6,18}=0.4283$, $\mathrm{P}=0.8505$ ) (Food supplement: $\mathrm{F}_{6,18}=0.4335, \mathrm{P}=$ 0.8470; one-way RM ANOVA)] (Figure 1B). The testis volume under LDL (16L: 8D) and control (NDL) groups gradually increased on 60 days and maintained until the end of experiment (Figure 2b and f). Maximum testicular growth was observed on 90 days in the control group (NDL), but the maximum testicular growth was noticed at 150 days in both groups under 16L: 8D. Statistically significant difference occurred on only food supplement group of LDL (Food supplement: $\mathrm{F}_{6,18}=5.603, \mathrm{P}=0.0020$ ) (Figure 1D) and NDL group $\left(\mathrm{F}_{6,18}=8.973, \mathrm{P}=0.0001\right.$; one-way $\mathrm{RM}$ ANOVA) (Figure 1D). Molting in body feathers started at six weeks in birds exposed to long day length $(16 \mathrm{~L}$ : 8D) in both groups and they respond similar in all the groups including natural day length group (NDL) (Figure 2A and B). But the molting on body feather was unaffected in groups (both) of short day length (8L: 16D) (Figure 2A). The peak response was significantly different in these groups [8L:16D (Food adlibitum) $\mathrm{F}_{12,36}=1.000, \mathrm{P}=0.4685$; Food supplement - $F_{12,36}=2.68478, P=0.0109 ; 16 \mathrm{~L}: 8 \mathrm{D}$ (Food adlibitum) $\mathrm{F}_{12,36}=0.9164, \mathrm{P}=0.5408$; Food supplement - $\mathrm{F}_{12,36}=5.194, \mathrm{P}<0.0001$; NDL $\mathrm{F}_{12,36}=9.039, \mathrm{P}<0.0001$; one-way $\mathrm{RM}$ ANOVA) (Figure 2A and B). The early initiation of feather regeneration on primaries was observed on group 1 (group 1- $\mathrm{F}_{12,36}=3.261, \mathrm{P}=0.0030$ ) (Figure 2C). 


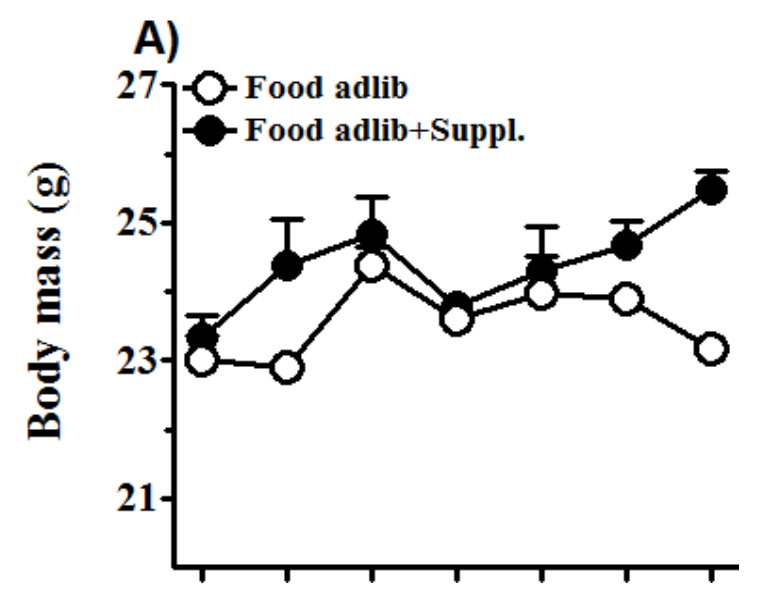

C)
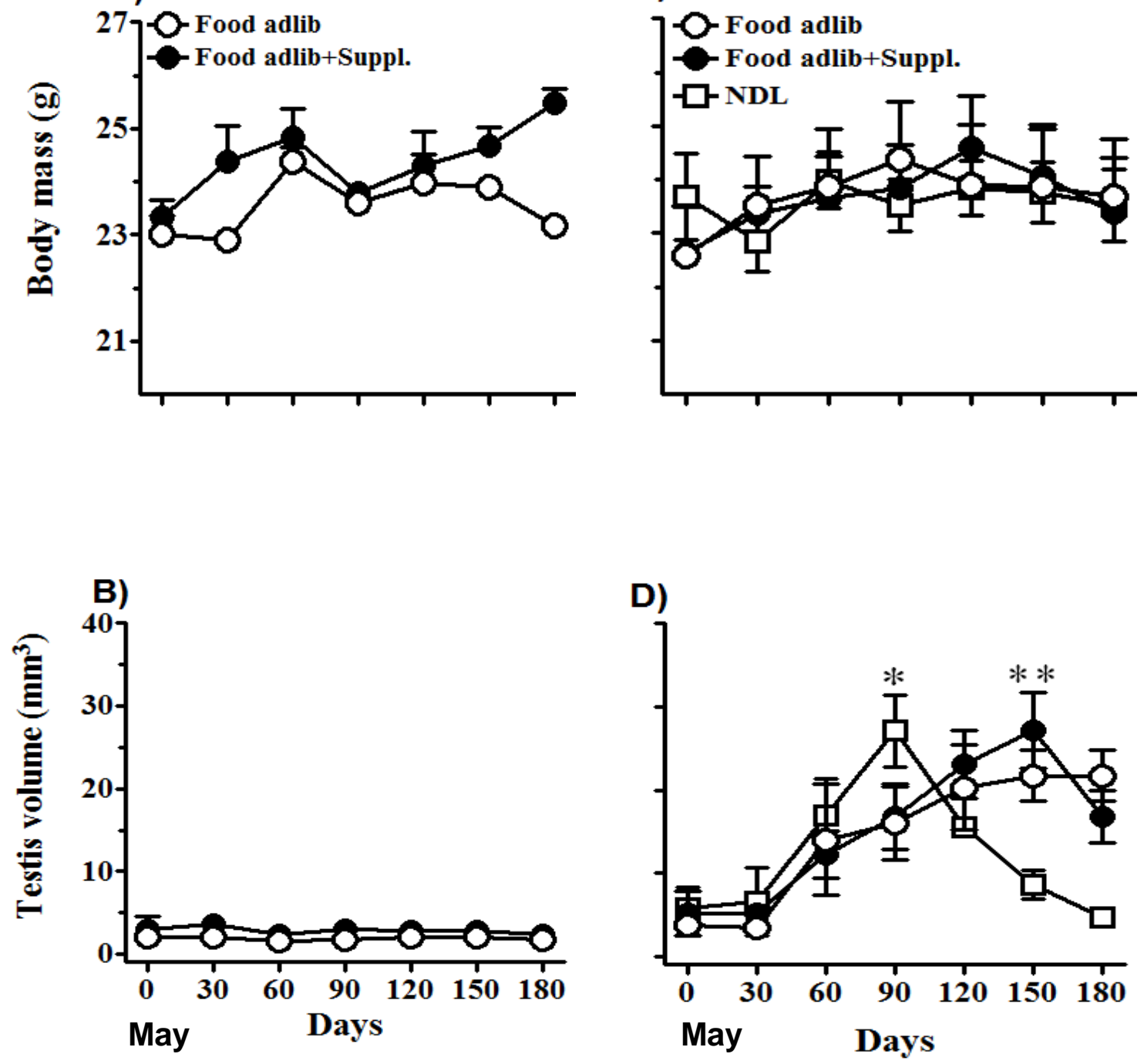

Figure 1. Mean $\pm \mathrm{SE}$ of body mass $(\mathrm{A}$ and $\mathrm{C}$ ) and testicular volume (B and $\mathrm{D})$ of photosensitive male Indian weaver bird exposed under SDL, LDL and NDL for 180 days. Each symbol represents mean $(n=4)$ and vertical line on it indicates the standard error. Significance of difference at $\mathrm{P}<0.05$ level: Asterisks indicate significance of difference compared to initial value $(*=\mathrm{NDL}$ and $* *=$ Food $a d l i b+$ Supplement food; one-way RM ANOVA; Newman-Keuls post hoc test). 
SDL (8L:16D)

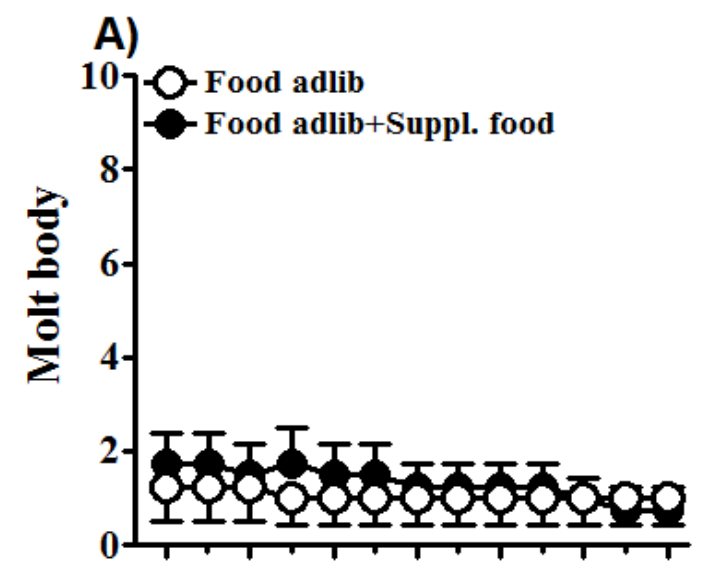

B)

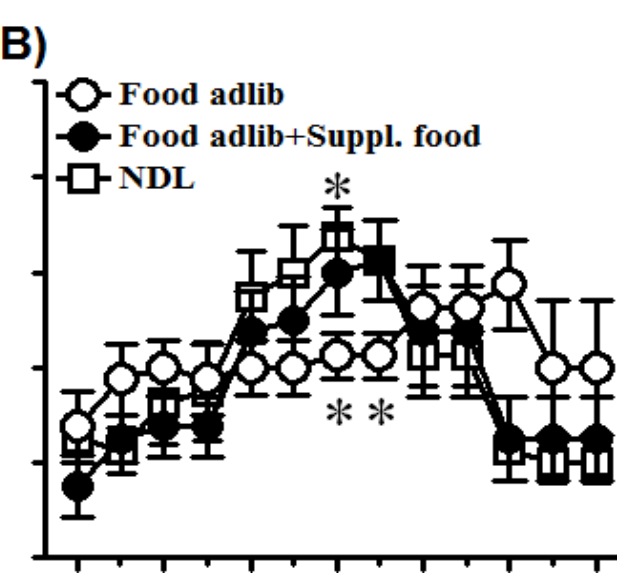

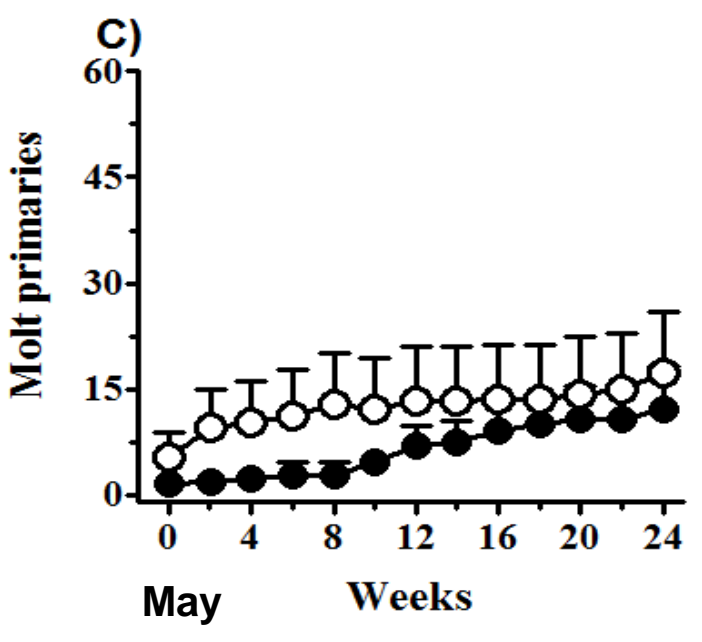

LDL (16L:8D) \& NDL

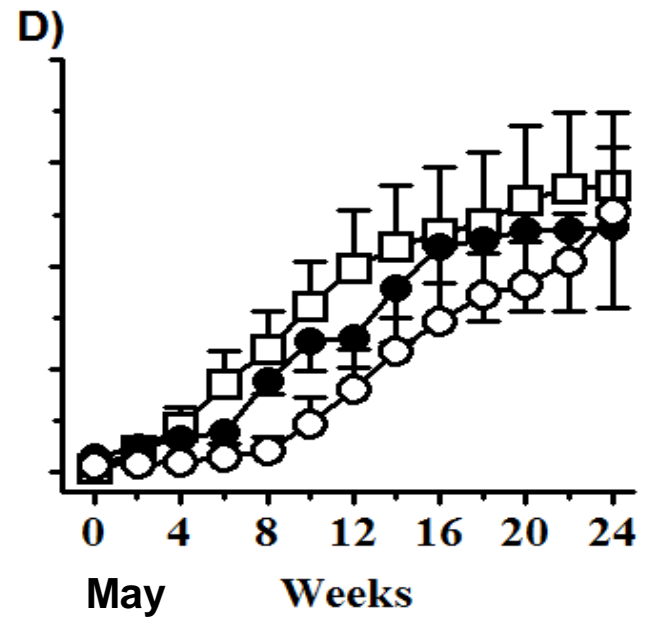

Figure 2. Effect of food (adlib/supplementary) on body molt (A and B) and wing primaries (C and D) of photosensitive male Indian weaver bird exposed under SDL, LDL and NDL condition for 24 weeks. Each symbol represents mean $(n=4)$ and vertical line on it indicates the standard error. Significance of difference at $\mathrm{P}<0.05$ level: Asterisks indicate significance of difference compared to initial value $*^{*}=$ NDL and $* *=$ Food adlib + Supplement food; one-way RM ANOVA; NewmanKeuls post hoc test). 
Malik et al.
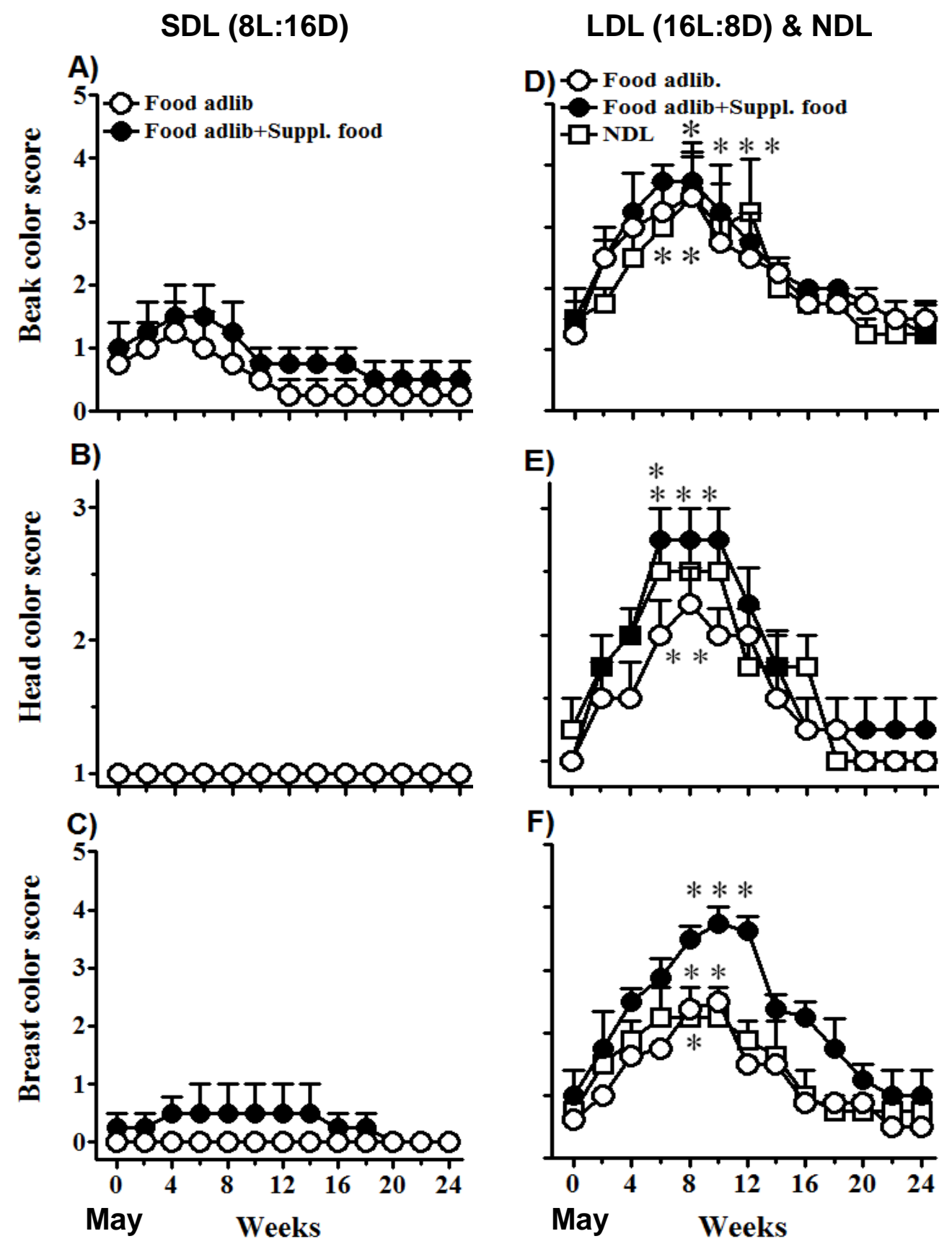

Figure 3. Effect of food (adlib/supplementary) on beak color (A and D) and plumage (head and breast) color (B, E and C, F) in photosensitive male Indian weaver bird exposed under SDL, LDL and NDL for 24 weeks experiment. Each symbol represents mean $(n=4)$ and vertical line on it indicates the standard error. Significance of difference at $\mathrm{P}<0.05$ level: Asterisks indicate significance of difference compared to initial value $(*=\mathrm{NDL}, * *=$ Food $a d l i b$ and $* * *=$ Food $a d l i b+$ Supplement food; one-way RM ANOVA, Newman-Keuls post hoc test). 
Table 1.Biochemical measurements of Ploceus philippinus exposed to short (8L: 16D) and long photoperiod (16L:8D). Initial values are mean \pm SEM of all birds.

\begin{tabular}{|c|c|c|c|c|c|c|c|c|c|c|c|c|}
\hline \multirow[t]{2}{*}{ S. $\mathbf{N}$} & \multirow{2}{*}{$\begin{array}{l}\text { Biochemical } \\
\text { Parameters }\end{array}$} & \multirow{2}{*}{$\begin{array}{l}\text { Initial } \\
(\text { day 0) }\end{array}$} & \multicolumn{2}{|c|}{$\begin{array}{l}\text { Group-1 (8L:16D) } \\
\text { Food adlibitum }\end{array}$} & \multicolumn{2}{|c|}{$\begin{array}{l}\text { Group-2 } \\
\text { (8L:16D) } \\
\text { Food adlib.+ } \\
\text { supplement }\end{array}$} & \multicolumn{2}{|c|}{$\begin{array}{l}\text { Group-3 } \\
\text { (16L:8D) } \\
\text { Food adlibitum }\end{array}$} & \multicolumn{2}{|c|}{$\begin{array}{l}\text { Group-4 } \\
\text { (16L:8D) } \\
\text { Food adlib. + } \\
\text { supplement }\end{array}$} & \multicolumn{2}{|c|}{$\begin{array}{l}\text { Group-5 } \\
\text { (NDL) } \\
\text { Food adlib. + } \\
\text { supplement }\end{array}$} \\
\hline & & & Day 90 & $\begin{array}{l}\text { Day } \\
180\end{array}$ & Day 90 & $\begin{array}{l}\text { Day } \\
180\end{array}$ & Day 90 & $\begin{array}{l}\text { Day } \\
180\end{array}$ & Day 90 & $\begin{array}{l}\text { Day } \\
180\end{array}$ & Day 90 & $\begin{array}{l}\text { Day } \\
180\end{array}$ \\
\hline 1. & $\begin{array}{l}\text { Cholesterol } \\
(\mathrm{mg} / \mathrm{dl})\end{array}$ & $\begin{array}{l}168.67 \\
\pm 0.88\end{array}$ & 185.00 & 194.00 & 174.00 & 182.00 & 190.00 & 207.00 & 170.00 & 168.00 & 162.00 & 173.00 \\
\hline 2. & $\begin{array}{l}\text { Triglyceride } \\
(\mathrm{mg} / \mathrm{dl})\end{array}$ & $\begin{array}{r}172.00 \\
\pm 5.30\end{array}$ & 220.00 & 212.00 & 192.00 & 236.00 & 242.00 & 240.00 & 206.00 & 238.00 & 190.00 & 222.00 \\
\hline 3. & $\begin{array}{l}\text { Protein } \\
(\mathrm{gm} / \mathrm{dl})\end{array}$ & $\begin{array}{l}4.63 \\
\pm 0.09\end{array}$ & 4.30 & 4.80 & 4.60 & 4.90 & 4.20 & 5.20 & 4.60 & 4.70 & 4.30 & 4.60 \\
\hline 4. & $\begin{array}{l}\text { Albumin } \\
(\mathrm{gm} / \mathrm{dl})\end{array}$ & $\begin{array}{c}2.80 \\
\pm 0.06\end{array}$ & 2.40 & 2.40 & 2.50 & 2.50 & 2.30 & 3.00 & 2.60 & 2.80 & 2.20 & 2.70 \\
\hline 5. & $\begin{array}{l}\text { Glucose } \\
(\mathrm{mg} / \mathrm{dl})\end{array}$ & $\begin{array}{r}174.00 \\
\pm 6.94\end{array}$ & 210.00 & 306.00 & 212.00 & 275.00 & 194.00 & 240.00 & 220.00 & 235.00 & 204.00 & 260.00 \\
\hline 6. & $\begin{array}{l}\text { Calcium } \\
(\mathrm{mg} / \mathrm{dl})\end{array}$ & $\begin{array}{l}9.07 \\
\pm 0.19\end{array}$ & 8.80 & 9.00 & 9.20 & 9.40 & 9.40 & 9.20 & 9.00 & 9.40 & 9.60 & 9.00 \\
\hline 7. & $\begin{array}{l}\text { Sodium } \\
(\mathrm{mmol} / \mathrm{L})\end{array}$ & $\begin{array}{r}136.60 \\
\pm 1.27\end{array}$ & 138.70 & 136.20 & 142.80 & 134.50 & 144.60 & 137.80 & 140.20 & 138.20 & 142.40 & 136.70 \\
\hline 8. & $\begin{array}{l}\text { Potassium } \\
(\mathrm{mmol} / \mathrm{L})\end{array}$ & $\begin{array}{c}3.69 \\
\pm 0.08\end{array}$ & 3.62 & 3.82 & 4.23 & 3.84 & 3.84 & 3.62 & 4.26 & 3.62 & 4.26 & 4.17 \\
\hline
\end{tabular}

In other three groups (LDL and NDL), the initiation of feather regeneration on wings was started after 6 weeks but statistically these groups showed differential significant response during the period of experiment (group $3-\mathrm{F}_{12,36}=8.942$, $\mathrm{P}<0.0001$; group 4- $\mathrm{F}_{12,36}=4.734, \mathrm{P}<0.0001$ and group $5-\mathrm{F}_{12,36}=1.96, \mathrm{P}<0.0001$; one-way $\mathrm{RM}$ ANOVA) (Figure 2C and D). In group 2 (8L:16D), one of the four birds showed little black patches on the tip of beaks between 6-14 weeks. But the beak color of all birds of group 1 was unaffected during the period of experiment which exposed under $8 \mathrm{~L}$ : $16 \mathrm{D}\left(\mathrm{F}_{12,36}=3.105, \mathrm{P}=0.0042\right)$. In group 3 (16L:8D; Food adlibitum), three of four birds showed black beak with half part of the beak left with straw patches. In group 4, three of four birds showed black color of beak during 6-14 weeks cycle. In control (NDL), group two birds attained complete, while the other birds showed the black beak with half part of the beak left with straw patches. Statistically, group 4 (LDL) and 5(NDL) appeared significant differences in bill color (group 4- $\mathrm{F}_{12,36}=$ 4.143, $\mathrm{P}=0.0004$ and group $5-\mathrm{F}_{12,36}=5.626$, $\mathrm{P}<0.0001$; one-way RM ANOVA) (Figure $3 \mathrm{~A}$ and $D)$. The nuptial feather regeneration in head region was unaffected in group 1 and 2 which exposed under short day length (8L: 16D) with food adlibitum and supplement groups (Figure 3B). Early nuptial feather regeneration was observed on group $3\left(\mathrm{~F}_{12,36}=3.597, \quad \mathrm{P}=0.0014\right), 4$ and 5 $\left(\mathrm{F}_{12,36}=7.101, \mathrm{P}<0.0001\right)$ but the maximum nuptial feather of head region was found on group 4 [16L:8D (food supplement) $\mathrm{F}_{12,36}=7.341, \mathrm{P}<0.0001$; one-way RM ANOVA) (Figure 3E). Similar trend was found on breast plumage; but there was significant variation occurred in groups 3, 4 and 5 over the time of experiment (Group-3: $\mathrm{F}_{12,36}=4.433$, $\mathrm{P}=0.0002$; Group-4: $\mathrm{F}_{12,36}=15.22, \mathrm{P}<0.0001$, Group - 5: $\mathrm{F}_{12,36}=12.84, \mathrm{P}<0.0001$; one-way RM ANOVA) (Figure $3 \mathrm{C}$ and $\mathrm{F}$ ).

In biochemical measurements, there was variable change found on day 90 and 180 compared with initial value in all groups; cholesterol (day 90: $\mathrm{Gp} 3>\mathrm{Gp} 1>\mathrm{Gp} 2>\mathrm{Gp} 5>\mathrm{Gp} 4$ and day 180: $\mathrm{Gp} 3>\mathrm{Gp} 1>\mathrm{Gp} 2>\mathrm{Gp} 4>\mathrm{Gp} 5$ ), triglycerides (day 90: Gp3> Gp1 $>\mathrm{Gp} 2>\mathrm{Gp} 5>\mathrm{Gp} 4$ and day 180: $\mathrm{Gp} 3>\mathrm{Gp} 4>\mathrm{Gp} 2>\mathrm{Gp} 5>\mathrm{Gp} 1$ ), protein (day 90: $\mathrm{Gp} 2=\mathrm{Gp} 4>\mathrm{Gp} 1=\mathrm{Gp} 5>\mathrm{Gp} 3$ and day 180: Gp3 $>\mathrm{Gp} 2>\mathrm{Gp} 1>\mathrm{Gp} 4>\mathrm{Gp} 5$ ), albumin (day 90: Gp4 $>\mathrm{Gp} 2>\mathrm{Gp} 1>\mathrm{Gp} 3>\mathrm{Gp} 5$ and day 180: Gp3 $>$ Gp2 $>$ Gp5 $>$ Gp2>Gp1), glucose (day 90: 
$\mathrm{Gp} 4>\mathrm{Gp} 2>\mathrm{Gp} 1>\mathrm{Gp} 5>\mathrm{Gp} 3$ and day 180: Gp1>Gp2> Gp5>Gp3>Gp4), calcium (day 90: Gp5 $>\mathrm{Gp} 3>\mathrm{Gp} 2>\mathrm{Gp} 4>\mathrm{Gp} 1$ and day 180: Gp2= $\mathrm{Gp} 4>\mathrm{Gp} 3>\mathrm{Gp} 1=\mathrm{Gp5}$ ), sodium (day 90: $\mathrm{Gp} 3>\mathrm{Gp} 2=\mathrm{Gp} 5>\mathrm{Gp} 4>\mathrm{Gp} 1$ and day 180: Gp4 $>\mathrm{Gp} 3>\mathrm{Gp} 5>\mathrm{Gp} 1>\mathrm{Gp} 2$ ), and potassium (day 90: Gp2>Gp5>Gp4>Gp3>Gp1 and day 180: Gp5> Gp2>Gp1 $>$ Gp3=Gp4) (Table 1).

The present finding suggests that the role of food supplement on the photoperiodic induction of physiological responses in baya weaver. Body mass was increased under SDL and LDL in those birds which received the grains along with food supplement (Figure 1A and C). Testis growth was un-stimulated in SDL but inductive response on testis size was noticed in LDL and control group (NDL) in baya weaver. Weaver bird is long day breeding species and they do not show the photoperiodic response under the SDL (below the critical photoperiod), which indicates the importance of photoperiodic cues over an endogenous seasonal clock in control of reproductive cycle of weaver bird. Food is the most important ultimate factor which controls the timing of breeding cycle (Lack, 1968; Scheuerlein and Gwinner, 2002). Reynolds et al. (2003) reported the supplementary food help on the advancement of in egg laying. Similar finding were recorded in starlings, as food with supplement advanced egglaying on 5 days prior to control birds (Källander and Karlsson, 1993), but the food restriction affect the delayed egg-laying period (Meijer and Langer, 1995). Some opportunistically breeding species breed more directly in response to food. The crossbills (genus Loxia) breed at almost any time of the year when the food availability is abundant. So, the exact timing of breeding cycle depends upon food availability, but during gonadal regression, moult cannot appear even if food availability is not abundant (Hahn, 1995). In present investigation the early feather regeneration and testis growth was noticed on groups which received supplementary food along with grain. So, the current finding suggested that the supplementary food advance the breeding phase in this species. Feather (body and wing primaries) and nuptial plumage regeneration occurred earlier in supplementary food groups. Thus, physiological changes during breeding phase depend upon the food availability. Experiment of
Perrins (1970), the male and female require sufficient food for the maturation and production of sperms and eggs.

The modulating effect of food availability is restricted to the maturation of male and female reproductive system. So, the effect of food as an ultimate factor is to fine-tune with female reproductive stages within the physiological window defined by photoperiodically controlled gonadal growth-regression cycle. However, even in these species, gonadal growth-regression cycle appears to be regular seasonal events, and availability of food (Hahn, 1998; Deviche and Sharp, 2001). In nature, the exact timing of breeding cycle also depends on food availability along with light-dark cycle. Indian weaver bird is sub-tropical species and its breeding cycle is a single seasonal window. It is a monsoon breeder, when day length starts to decline but the food availability is abundant. Therefore, experiment that have offered food quality (grain as well as supplement food) to birds just prior to breeding phase in the tropical-zone advancing the transition into breeding cycle (Schoech and Hahn, 2007). Our results suggest that the availability and quality of food affect the morphological and physiological changes in this species.

The other investigation by Scheuerlein and Gwinner (2002) demonstrated the supplement food effect on breeding cycle of tropical bird (Stonechats) and finding suggested that food may be a cue for reproduction in tropical birds and supplementary food advanced the initiation of breeding cycle in African stonechats, Saxicola torquata, (Scheuerlein and Gwinner, 2002). The early reproductive cycle was noticed on other tropical species i.e. S. torquata, when food supplements given on prior to their breeding season (Class and Moore, 2013). Similar finding of food supplement effect on breeding season was reported on temperate-zone birds by Class et al. (2011).

Finding of our study suggest that food supplement modulate the testicular growth, body molt, bill pigmentation and plumage regeneration in weaver birds. So, the food availability and quality changes the response on moult and physiological characteristics (bill and plumage colour) of male Indian weaver bird. 


\section{Acknowledgments}

Generous financial support from the DST, New Delhi through research grant SR/SO/AS-70/2011) to SKB is gratefully acknowledged. We also thank the Chief Wildlife Warden, Uttar Pradesh Forest department, Lucknow for permitting us to work on this species.

\section{References}

Ali, S. and Ripley, S.D. 1974. Handbook of birds of India and Pakistan.Vol. 10. Oxford University Press, Bombay, London, New York.

Aschoff, J. 1981. A survey on biological rhythms. In: Handbook of Behavioural Neurobiology4, (Ed.) Aschoff, J., Plenum Publishing Corporation, New York, pp. 3-10.

Bhardwaj, S.K. and Pandey, R.K. 2014. Light intensity alters the stimulatory effects of long photoperiod, but does not alter critical photoperiod in the Indian weaver bird (Ploceus philippinus). J. Ornithol., DOI 10.1007/s10336014-1118-9.

Boswell, T. 1991. The physiology of migratory fattening in the European quail (Coturnix coturnix).Ph.D. Thesis, University of Bristol, UK.

Budki, P., Rani, S. and Kumar, V. 2009. Food deprivation during photosensitive and photorefractory life-history stages affects the reproductive cycle in the migratory redheaded bunting (Emberiza bruniceps). J. Exp Biol., 212: $225-230$

Bywalez, W.P. and Menegazzi, A. 2012. The dual-oscillator system of Drosophilamelanogaster under natural-like temperature cycles.Chronobiol. Int., 29: 395-407.

Class, A.M. and Moore, I.T. 2013. Effects of food supplementation on a tropical bird. Oecologia, 173: 355362

Class, A.M., Wada, H., Lynn, S. and Moore, I.T. 2011. The timing of life history stages across latitudes in Zonotrichia sparrows. Condor, 113: 438-448.

Daan, S., Barnes, B.M. and Strijkstra, A.M. 1991. Warming up for sleep - ground squirrels sleep during arousals from hibernation. Neurosci.Lett., 128: 265-268.

Daan, S., Dijkstra, C., Drent, R.H. and Meijer, T. 1988. Food supply and the annual timing of avian reproduction.Proc. 19th Int. Ornithol.Congr., 1: 392-407.

Deviche, P. and Sharp, P.J. 2001. Reproductive endocrinology of a free-living, opportunistically breeding passerine (white-winged crossbill, Loxia leucoptera). Gen. Comp. Endocrinol., 123: 268-279.
Dixit, A.S. and Singh, N.S. 2012. Seasonal variation in sensitivity of the photoperiodic response system in the subtropical tree sparrow (Passer montanus). J. Exp. Zool., 317: 488-498.

Dixit, A.S. and Sougrakpam, R. 2013. Photoperiodic regulation of seasonal reproduction, molt and body weight in the migratory male yellow-breasted bunting (Emberiza aureola). Anim. Reprod. Sci., 141: 98-108.

Hahn, T.P. 1995. Integration of photoperiodic and food cues to time changes in reproductive physiology by an opportunistic $\backslash$ breeder, the red crossbill, Loxiacurvirostra (Aves: Carduelinae). J. Exp. Zool., 272: 213-226.

Hahn, T.P. 1998. Reproductive seasonality in an opportunistic breeder, the red crossbill, Loxia curvirostra. Ecology, 79: 2365-2375.

Hau, M. 2001. Timing of breeding in variable environments: tropical birds as model systems. Horm.Behav., 40: 281290

Källander, H. and Karlsson, J. 1993. Supplemental food and laying date in the European starling. Condor, 95: 10311034.

Kumar, V., Singh, B.P. and Rani, S. 2004. The bird clock: a complex, multioscillatory and highly diversified system. Biol. Rhythm Res., 35: 121-144.

Kumar, V., Singh, S., Misra, M. and Malik, S. 2001. Effects of duration and time of food availability on photoperiodic responses in the migratory male blackheaded bunting (Emberiza melanocephala).J. Exp. Biol., 204: 2843-2848.

Lack, D. 1968 Ecological adaptations for breeding in birds. London, UK: Methuen.

Meijer, T. and Langer, U. 1995. Food availability and egg laying of captive European starlings. Condor, 97: 718-728.

Menegazzi, P., Yoshii, T. and Helfrich-Förster, C. 2012. Laboratory versus nature: the two sides of the Drosophila circadian clock. J. Biol. Rhythms, 27: 433-442.

Pandey, R.K. and Bhardwaj, S.K. 2011. Circadian and seasonal responses in Indian weaver bird: Subjective interpretation of day and night depends upon both light intensity and contrast between illuminations. Chronobiol. Int., 28: 758763.

Pandey, R.K. and Bhardwaj, S.K. 2013. Effects of light intensity on circadian activity behavior in the Indian weaverbird (Ploceus philippinus).Indian J. Exp. Biol., 52: 510-515.

Perrins, C.M. 1970. The timing of birds' breeding seasons.Ibis, 112:242-255. 
Rani, S., Singh, S. and Kumar, V. 2007. Photoperiodism, pineal clock and seasonal reproduction in the Indian weaver bird (Ploceus philippinus). J. Ornithol., 148: S601S610.

Reynolds, S.J., Schoech, S.J. and Bowman, R. 2003. Nutritional quality of prebreeding diet influences breeding performance of the Florida scrub-jay. Oecologia, 134: 308316.

Saxena, R.N. and Thapliyal, J.P. 1962. Male hormone and bill pigmentation in baya, Ploceus philippinus (Linn.).2nd All India Congr.Zool., Abstract 29.

Scheuerlein, A. and Gwinner, E. 2002. Is food availability a circannual zeitgeber in tropical birds? A field experiment on stonechats in tropical Africa. J. Biol. Rhythms, 17: 171180.
Schoech, S.J. and Hahn, T.P. 2007. Food supplementation and timing of reproduction: does the responsiveness to supplementary information vary with latitude? J. Ornithol., 148: S625-S632.

Thapliyal, J.P. and Saxena, R.N. 1961. Plumage control in Indian weaver bird (Ploceus philippinus). Naturwissenschaften, 24: 741-742.

Trivedi, A.K., Rani, S. and Kumar, V. 2006. Control of annual reproductive cycle in the subtropical house sparrow (Passer domesticus): evidence for conservation of photoperiodic control mechanisms in birds. Frontiers in Zoology, 3: 12 .

Wingfield, J.C. 1980. Fine temporal adjustment of reproduction functions. In: Avian Endocrinology (Ed. by A. Epple and M.H. Stetson), Academic Press, New York, pp. 367-389. 